\title{
LIFE AND DEATH IN NONNUS' DIONYSIACA: FILLING THE VOID AND BRIDGING THE GAP
}

\author{
R. Newbold
}

\begin{abstract}
A time to weep, and a time to laugh/A time to mourn, and a time to dance.
\end{abstract}

(Ecclesiastes 3.4)

[Nonnus] encrusted his poetry with voluptuous idylls and cosmological secrets.

(R. Calasso) ${ }^{1}$

The thesis of this paper is that the void, the sense of emptiness, created by some form of loss, is, to a considerable extent, filled and bridged by a number of activities and motifs that pervade the Dionysiaca. Nonnus projects a vision of life so resonant, full and fertile that it mostly overwhelms forces and behaviour that make for sterility and emptiness. However, constant effort is needed by various individual entities to harmonise polarities, and to keep the cosmos orderly and busy spinning cycles of germination, growth, death and reseeding/rebirth. Immortals, especially deities, have a greater capacity to relieve their own bereavements, separations and loss, including the gaining of forms of immortality for favoured individuals. For most mortals, reminders of the nature and power of life's eternal flow is no guarantee of individual post-mortem survival or of the healing of wounds incurred by the loss of someone or something precious. But the intimations of immortality and the resources for solace and recovery are persistent and insistent in Nonnus' narrative.

Many people die in the Dionysiaca, leaving behind grieving relatives, friends, followers, comrades, compatriots. The war against the Indians (Books 13-40, with many digressions) involves heavy mortality. There are other battles. There are at least 111 occasions when people are killed, commonly en masse and in large numbers, in warfare or cataclysm. People can be killed by weapons or missiles, including the thyrsus and the thunderbolt, that decapitate or penetrate them. Or they are killed by being hanged, drowned, thrown and trampled, devoured, burnt, or turned into stone by Medusa's gaze. Results of death include the mockery, flaying, dismemberment and display on city gates of corpses; corpses choking and bloodying rivers; the departure of souls to Hades, the visitation of the living by ghosts; transformations into flowers; burials and funeral rites. Naturally, there is also much activity to discharge the pain through grief and lamentation. There are at least 31 occasions when Nonnus reports death causing grief, sorrow, lamentation for the living, plus two occasions when the prospect or fear of loss causes grief. Twenty of these instances involve humans as mourners, three immortals such as nymphs and pans, and nine deities. To some extent, immortals experience the death of others differ- 


\section{LIFE AND DEATH IN NONNUS' DIONYSIACA}

ently. They are not thereby reminded of their own mortality and impending demise and they are prevented by their immortality from rejoining the deceased in Hades, if that is the deceased's destination. While nymphs, pans, satyrs, sileni can numb the pain of loss with wine, deities cannot. They have different resources for overcoming grief but may feel as keenly as any mortal the deaths of human or semi-divine offspring or favourites. When Titans kill his son Zagreus, Zeus has the capacity not only to imprison them in Tartarus but also to inflict a massive conflagration upon their mother, Gaea (6.206-23).

Death occasions the usual marks of grief, whether by individuals or groups (an asterisk indicates a mark not manifested by a deity): tears, groans, wailing and dirges, withdrawal, depression and hiding, gloomy visage, cessation of revelry, speechlessness and petrifaction*, violence (sometimes murderous), anger, threats and reproach, scoring cheeks*, beating breasts*, cutting, loosening or fouling* hair, tearing clothing, rolling in dust*, going unshod and unveiled*, seeing the lost one in a dream, aimless wandering, mourning for the deceased's lost future, abstinence from food and drink*, thoughts of suicide*, gathering up remains, and honouring the corpse and the deceased's memory with epitaphs and funeral rites, such as the games in Book 37 that mourn, honour and partially immortalise Opheltes. ${ }^{2}$ The lengthiest narration of a particular loss and subsequent grief concerns the death of Ampelus. Manifestations of grief include Dionysus' regret for promise unfulfilled, the plea to Zeus to let Ampelus speak again, self-blame, threats to kill whatever animal was responsible for Ampelus' death, and floral and other tributes to his memory.$^{3}$ There are other, non-fatality forms of loss which Nonnus reports causing distress, sometimes so severe as to involve a social death and to drive mortals to (thoughts of) suicide. These losses total 33 and include loss of virginity, homeland, freedom; loss of special precious objects or attributes such as the iris, anemone, olive-tree; loss of activities, prestige and honour; and loss of the affections, identity or presence of a beloved or dear one, such as when Dionysus abandons the Bacchants and flees under the sea to escape Lycurgus (21.178-99). There is also a feared loss, such as Demeter fearing the loss of her daughter in marriage to someone like Hephaestus (6.1-108). Twenty-three of these instances involve human grievers, four non-god immortals, seven deities. The discussion of loss, and responses to it, that follows will focus first on actual or feared deaths.

They most grieve who grieve alone, and the most important healer of bereavement, apart from the passage of time, is experiencing the company of and having some contact with others. This might involve participation in communal rituals of mourning, which can include eating, drinking, dancing, praying and wailing together. Or it can be sympathetic embraces or body language, consolatory written or spoken words, comforting presence or assistance. ${ }^{4}$ The sensory mode most affected by bereavement is touch. ${ }^{5}$ Contact, whether the meeting of flesh and flesh or flesh and clothing, or the sort of contact involved in social intercourse, is ruptured by death and needs to be restored in some way. There is an aching void, an emptiness, a hole, a gap where there was once a 


\section{R. NEWBOLD}

fullness, a presence, a sufficiency. Filling and bridging this with objects and activities that proclaim or stand for life, fertility, abundance and what was special about the deceased, are universal responses to bereavement. The need for strong sensation, for vivid sensory experience that reconnects one with the physical world and counteracts feelings of numbness, is provided, inter alia, by activities such as hair-tearing, breast-beating and facial laceration. Withdrawal from company is an understandable reaction to grief (it saves energy when a sense of depletion and exhaustion rules) but maintaining or re-establishing contact with others not only hastens healing, it respects the life of the deceased. A source of torment for the living is not knowing what has happened to the dead, and worry that the deceased might suffer an unduly miserable afterlife through not being buried properly and not being given the proper funeral rites. Hence the initial frantic but unsuccessful search for Actaeon's scattered remains by his parents Aristaeus and Autonoe, when they learned that their son had been dismembered. Actaeon appears in a dream to Aristaeus, relates his fate and begs for a proper burial in a tomb and a depiction of him on it as a human-headed fawn, but not a verbal account of his fate, as that would unduly distress the wayfarer who read it. Autonoe was able to gather some remains and carry out his wishes. ${ }^{6}$ More will be said below about neutralising the void with company and fullness but, first, some observations on verbal consolation of the bereaved. In the Dionysi$a c a$, there is not much of it that is entirely apt.

As Cadmus lamented the catastrophe of Pentheus' death, Dionysus 'soothed his sorrowful moans with healing words. ${ }^{7}$ But when Autonoe consoles her sister, Agave, she elaborates upon how much more painful it was to endure her son Actaeon's death (46.320-43). No wonder line 352 is: 'She (Autonoe) spoke and Agave childmurderer sorrowed yet more.' Dionysus attempts to console Autonoe by suggesting that Actaeon is not really dead (44.283-319). Dionysus' consolation of his new bride, Pallene, after he has killed her father, firstly impugns him as a wicked and incestuous man without whom she is much better off. He then goes on to speculate that she is more likely the daughter of Ares and Aphrodite, or Hermes and Peitho (48.205-37). Much more impressive is the Fate Atropos' gesture in consoling Dionysus with the news that his late beloved, Ampelus, will cheat Hades and turn into the vine. He will provide a new, delicious and cheering drink, and be worshipped with dance, chant and music. Apollo, his favourite Hyacinthus having become the iris, will be jealous, she says. 'Lord Bacchos has wept tears, that he may wipe away man's tears' (12.142-71). Such an immortalisation through metamorphosis into a plant had been prefigured by a consolatory tale told by Pan to the mourning Dionysus. Pan had begun his consolation by telling Dionysus to forget Ampelus and find another youth: 'court a better boy,' as the West Wind had, turning to Cyparissus after losing Hyacinthus: when a gardener 'sees a flower on the ground lying in the dust, he plants another new one to comfort him for the dead one' (11.356-68). Calamus and Carpus, Pan continues, were lovers, and when the latter drowned, the former, overcome by the loss, likewise committed himself 


\section{LIFE AND DEATH IN NONNUS’ DIONYSIACA}

to a watery grave (11.369-481). The result, by some unexplained process, was that they lived on forever as Reed and Fruit, and were joined by Cissus, when his corpse turns into the ivy that is always present when Dionysus is worshipped (12.188-92). Moving from verbal consolation-cum-recompense to nonverbal recompense and comfort, it is hard to beat Zeus, moved by pity, not only catasterising Erigone's father, Icarius, murdered by drunken rustics, but then making stars of her and the faithful dog (Sirius), so that all three are reunited in heaven (47.246-55).

Returning to the great gift to humanity that was the grape-vine, wine is described as healing, joy-bringing, the 'cure-trouble, mindsolacing drops', 'no-sorrow grape', 'nomorepain liquor', 'sorrowconsoling wine' and has a prominent role to play in the mourning that follows the death of King Staphylus. ${ }^{8}$ Dionysus also gives it, mixed with a drug, to the wailing and lamenting Agave and Autonoe 'as a drink to lull their troubles'.?

Something that would console both the bereaved but also those about to die would be, if not full immortality, then at least a partial immortality, which would diminish the prospect of complete extinction and oblivion. Having children who would care more than most about preserving and tending your grave, your memory and your position in a lineage was one way. Part of the anguish in grieving for dead children was the threat this posed to one living on in posthumous memory (cf. 30.60, 32.187). Initiation into the mysteries would presumably involve learning something about immortality and, allegedly, improved one's prospects in the afterlife. ${ }^{10}$ It is not certain that initiation into the Dionysian mysteries was understood to be available before the birth of Dionysus' son, Iacchus (48.965-68) Several people, Calamus, Carpus, Hymnus, Orontes, earn or hope for epitaphs inscribed on a durable surface. ${ }^{11}$ Being honoured by funeral rites (which could include placing a lock of the deceased's hair on the soon-to-be-cremated corpse), contests and games, particularly if presided over by a god, such as those for Staphylus in Book 19 and Opheltes in Book 37 , helped one live on in memory while at the same time the group activity eased the grief of survivors.

A more enduring form of immortality, for as long as there is viticulture in fact, is that achieved by Staphylus, Methe and Botrys, who live on as names for grapes and wine, or as vegetative personifications, like Ampelus and Cissus. Together with Pithos they are part of the terminology of wine production and the cult of Dionysus $(19.44-58,20.127-35)$. This is a kind of lexical immortality. Also, Methe is promised a place in heaven as a star, to be at Dionysus' side and to serve him wine. The daughter of Dionysus and Nicaea, Telete, lives on in the terminology of his mysteries. Nicaea herself is immortalised by having a city named after her (16.403-15). Beroe gives her name to a city famous as a centre of Roman law. The Indian warrior Orontes drowns himself in and gives his name to the river Euphrates (17.287-89). Living on as plants, Ampelus, Hyacinthus (iris) and Adonis (anemone) eased the grief of Dionysus, Apollo and Aphrodite (2.81-84, 88-90, 3.153-63), and one could posit some mutual conso- 


\section{R. NEWBOLD}

lation for father Staphylus, mother Methe and son Botrys in the way they endured in everyday life. The most spectacular form of immortality, however, was catasterism. Shining forever in the night sky, one dwelt in that part of the cosmos inhabited by deities. As Hermes says, 'What could Ariadne wish more welcome than to live in the heavens and give light to the earth?' (47.703f.). Beloved of Dionysus and mother of a number of his children, Ariadne was raised to the sky as the constellation Corona, so that she would be near Dionysus in Olympus. He was thus spared the pain of a truncated relationship (48.969-73), just as Icarius, Erigone and their dog were. Earlier, Semele (as Thyone, 8.40718) and Bacchant nurses of Dionysus (who include Ambrosia, 21.295-98) were catasterised, and this fate was prophesied by Thetis for the Bacchant Chalcomede (33.370-78). Being in some way associated with Dionysus and the propagation of wine enhanced prospects for catasterism. Ambrosia punished Lycurgus for attacking Dionysus and Chalcomede was a formidable Bacchant warrior. Less clear are the merits of catasterised Andromeda and the monster that Perseus had to rescue her from, ${ }^{12}$ Phaethon, whose mad ambition to drive his father Helios' chariot across the sky caused widespread devastation and carnage, and Eridanus, the river that was a major victim of this folly. ${ }^{13}$ The paradigm for a hero immortalised for his great deeds is Heracles, frequently mentioned in the Dionysiaca and addressed as the Starclad, Astrochiton, and equated with the Sun by Dionysus (40.366-410). While the immortality of Perseus is less stellar, he too enjoys immortal fame for great deeds. As Discord reminds Dionysus, the path to Olympus must be won by hard work and great deeds (20.95-97). Dionysus' own apotheosis was based on such achievements but the moral economy of the poem is challenged by the catasterism, by his champion Hera, of the appalling Lycurgus, king of Thrace and violator of every civilised norm. ${ }^{14}$ As the above examples illustrate, winning immortality as a star or plant might be fortuitous or ordained by Fate, as seems to have been the case for Semele and Ampelus (7.121, 12.101f.). It might depend upon one being the protégé of, or upon catching the eye of, a deity alert for young and beautiful humans. Being associated with Dionysus helped. Immortality might even depend on one being, in some way, a victim of a deity's actions, and eliciting an impulse to make up for sufferings incurred. One did not have to be especially deserving, although Dionysus, Heracles and Perseus are positive examples. When we turn to losses other than a life, reactions to a (prospective) loss, and resources for comfort and support, we see again the shortcomings of (would-be) consolers. A Hamadryad, fearing the loss of her maidenhood in the upheaval caused by Typhon, ponders becoming a poplar to weep amber tears for herself, and not, like Phaethon's sisters, for their brother (2.152-57). She sees the distress of a fellow Hamadryad but instead of comforting her bemoans her own perils (2.112-62). At this time of the Typhonic upheaval, gods, goddesses, Pan and nymphs mourn only for the things lost that are special to them at, such as the iris, anemone, olive-tree (2.81-93). Electra consoles the wandering exile, Cadmus, by dilating upon her own loss and deprivation (3.326-54, adding that she hopes to take her place in 
heaven as one of the Pleiades). Pan, initially highly amused, pities and advises Dionysus, love-lorn for Beroe, but begins with a reference to his own sufferings. ${ }^{15}$ Nicaea, also a victim of rape and impregnation by Dionysus, 'consoles' Aura with a mixture of reproach of Aura and regret for her own loss of virginity (48.811-27). On the other hand, there is genuine sympathy and pity from Electra for her foster-daughter Harmonia, distressed at having to marry a poor wanderer like Cadmus and to leave her adoptive home and family. ${ }^{16}$

Cadmus too had lost his home and family but deprivation turned to enhancement when he founded Thebes and a dynasty and, with Harmonia, became a grandparent of Dionysus. His sister, Europa, loses her home, family and maidenhood but gives birth to a semi-divine child and king of Crete. ${ }^{17}$ Abandoned on Naxos by Theseus, Ariadne mourns the loss of her father, homeland and bridegroom. She says she will do anything to get Theseus back. Dionysus comforts her, offering himself as husband, and promises her a place in the heavens, enhancement indeed ('she throbs with joy', 47.453), but this is somewhat undercut by his subsequent desertion of her, for which she upbraids him in a dream (47.295-471, 48.530-65). Demeter, fearing the loss of her daughter in marriage is comforted by Astraeus, the god of Prophecy, who tells her she will gain by becoming the great goddess of agriculture. ${ }^{18}$ The passage of time resolves and corrects some losses ${ }^{19}$ but not others. ${ }^{20}$ The deprivation of his right hand in battle spurred one of Dionysus' troops to enhance his reputation and memory by killing the perpetrator and dying a glorious death surrounded by Indians (28.126-57).

To review: reactions to and consequences of lost life or some other form of loss depend partly on whether the afflicted is mortal or immortal. Something positive can come from an unwelcome experience. The sting of extinction or oblivion can be mitigated or even wholly avoided. People are by no means devoid of sympathy, pity and compassion for the bereft. However, true sympathy, gentle touch and helpful consolation from individuals are by no means automatic. Although there is much group and shared activity and hence, one would surmise, much bonding through shared experiences in battle, hardship, travel, dance, feasting, carousing and grief, when individuals interact with each other, they often do so in an alienated, cold, autistic, harsh, unfeeling or unsympathetic way, so that, for example, many speeches are addressed to no-one in particular and, typically, they are charged with scorn, derision, reproach and abuse. ${ }^{21}$ Such speeches are attempts to belittle and belong to a larger and endemic struggle for dominance, which in turn may suggest a failure properly to connect and relate, and are perhaps a recognition of an inner void that needs to be filled with self-inflation, grandiosity and identification with a figure of omnipotence. Physical touch, moreover, is violent (and therefore highly sensate), or perfunctory or made to seem accidental. Soft touch is written out of the poem. There is much beating and whipping and binding. ${ }^{22}$ Gentle, consensual sex is a source of anxiety. Rape, quasi-rape, seduction with an ulterior motive, and the non-coital production of life are 'safer' ${ }^{23}$ In short, solace from others in 


\section{R. NEWBOLD}

the Dionysiaca is not always forthcoming, but it is the sympathy and support of others for one's loss that is so crucial for easing the pain. One sees this clearly in the case of the nymph, Aura. Made to feel even more keenly the pain and shame of her lost virginity by Artemis' taunts (48.749-82, 832-47), she shows the typical response to dishonour and perceived social death: murderous rage against others and the self. Shame is lethal. Isolated and alone, she kills any herdsmen and hunters she encounters, kills one of her newborn twin sons, seeks Dionysus in order to kill him too, rages against Athena, Artemis and Aphrodite, and then commits suicide (48.662-84, 713-19, 917-24, 928-42). In contrast to this behaviour by an isolated individual, the communal and ritualistic outpourings of grief which are common in warfare help ease the grief of not just lost relatives and comrades but bleak and degrading future prospects. In any circumstances, religious cult activity, too, which may include feasting, carousing, dance, chant, song and drumming, is another effective way of establishing connection and communion, and hence a sense of mental and physical wellbeing. 'At that moment of connection, the emptiness and void are gone.' ${ }^{24}$ In other words, there are numerous group activities in the poem that restore morale and reintegrate the individual with the outer world when third parties, who evince a marked tendency towards self-absorption, abuse, violence and sadism, exacerbate or fail to ease sorrow.

For all the scenes that portray the aching void and incomplete repair of loss, the poem in so many ways is about a world of plenty, and of joyful fullness and expansiveness; about the author's exuberant imagination; about pullulating, sprouting, ejaculating, ${ }^{25}$ condensing volcanic life; about creation, procreation, seeding and growing; about community, fellowship, joint activities; about new forms that result from all manner of metamorphoses, transmigrations and irregular conceptions (e.g., parthenogenesis, autochthony); about changes which could foster the belief that there is no death, only changes of state and form; ${ }^{26}$ about song, dance, chant, war-cries and throbbing drumbeats that fill the air, shake the ground, and have an intoxicating effects on participants akin to wine; ${ }^{27}$ about revelry by human and nature spirits (satyrs, pans, nymphs) that expands on occasion to include animals, plants, rocks; about a dynamic, restless celestial world that constantly impinges and creates images of itself upon the terrestrial, mortal world; about a plenum that is constantly scored, scratched, engraved; ${ }^{28}$ about a multi-nippled cosmos rich with easily accessible streams of wine, milk and honey that fill the imbiber; about an economy of abundance where boons and gifts are common and where rivers bear gold and amber; about wine that not only fills the stomach but drowns sorrow, enlarges consciousness, facilitates conviviality and bonding, and infuses courage, confidence and good cheer. Nonnus' cosmos is highly sexualised one. It is also relentlessly cyclic and orchestic, replete with the circular, spiralling, twisting trajectory and choreography that characterises patterns of terrestrial growth. These patterns cohere with the motion of the heavenly bodies and render visible what we now know is going on in the invisible, orbiting, dancing subatomic world that cor- 


\section{LIFE AND DEATH IN NONNUS' DIONYSIACA}

responds to the macrocosmic movement of solar systems and galaxies and subtends life. ${ }^{29}$ To dance in step with this motion is therefore to accept an invitation to harmonise with the flow of life's currents. With so many images and motifs of fullness and abundance, one might ask: what room is left for sterility and emptiness?

Nonnus describes a landscape filled with sound where the sonic driving produced by pounding on drums would fill the brain with an oceanic, timeless, ineffable, connected feeling that banishes the void and removes the sense of separation. Sonic driving can produce a trance state that provides the means for possession and transformation by a deity. Dancers bond with each other in shared delight and excitement, and dance can give one a sense of generating space from within. Drumming and dancing are about filling space with nature and divinity, resonance and echo, about invoking Dionysus, whose charismatic presence alone may not have been enough to comfort followers who spent so much time in strange lands amid strange peoples. ${ }^{30}$ Given all this, there is ample opportunity for mortal mourners in particular to be distracted from their pain, extricated from the pull of the void and reoriented towards the ambient plenitude, partly via appreciation of the fecundity, redundancy ${ }^{31}$ and fruitfulness of nature, partly via vibrant group activity. ${ }^{32}$ There are in the poem, however, also scenes of barrenness and desolation, which are like sad and sorrowful voids. In worlds dislocated and rendered unfruitful by disorder, it is the cessation of dance and weaving that contributes to and signifies this sterility. When Dionysus goes missing in battle, it is his music and dance that his followers miss as well as his leadership. $^{33}$

Nonnus had over a millennium of literature and thought to draw upon and many of his debts have been identified in monographs, articles and commentaries. Influences include Neoplatonic and Hellenistic. Hermeticism, Stoicism and Orphism, and the general intellectual ferment, pagan and Christian, which invigorated late antiquity. Christianity had reinforced the translation upwards of the realm of the blessed afterlife for mortals that philosophy had been positing for at least a millennium, going back to Pythagoras and Plato and their belief in the astral origins of souls, and therefore the place of their ultimate return. ${ }^{34}$ The Dionysiaca coheres with this tendency not just in the frequent mention of the heavens as a realm of activity and a destination for the fortunate and deserving, but also in the neglect of the underworld as a site for activity or visits. There are some (22) references to Hades the inexorable and his grim rivers, but only one katabatic journey, by Hera. ${ }^{35}$ So ready to adapt or seek to rival a Homeric episode, and with the well-known tradition of Dionysus' descent to Hades to rescue his mother offering an obvious pretext for such a treatment, Nonnus passes up the opportunity and has Semele immediately catasterised after her incineration.

In Nonnus there are many references to the beauty of mortals and immortals, a few to the joyous beauty of nature and to magnificent artefacts. ${ }^{36}$ Beauty can do much to make bearable bereavement and the existential, primal pain of liv- 


\section{R. NEWBOLD}

ing in a melancholy vale of tears, fallen from a state of grace as spirit enters flesh. We may enjoy precious glimpses and tear-jerking, echoing reminders of an Edenic, supermundane, transcendent, archetypal, primordial, eternal realm of beauty incarnate when we encounter something exquisitely beautiful on earth or gaze to the heavens and see the jewel-like beauty of the clear, starry sky. ${ }^{37}$ Accepting nature's bounty and responding to beauty in the world, finding joy therein, and refusing to turn to stone are helpful ways of honouring the dead and even recalling their vital, vibrant and often beautiful presence. ${ }^{38}$ Beauty comes in many guises. In humans or flowers it is all too transient. Insofar as beauty is characterised by order and harmony, it is at the heavens and at certain patterns on earth that mortals in Nonnus are encouraged to gaze and become part of if they would apprehend divinity. By grasping and celebrating the infinite and archetypal through contemplating a finite pattern or by replicating heavenly movements, earthlings currently separated from the Sacred Presence narrow the gulf between above and below. In the physical world, the annual passage of the sun brings about the rhythmic, seasonal ebb and flow of life and creation. The shorter lunar cycles, lunations, also illustrate ebb and flow as the moon waxes and wanes. Nature provides constant reminders of persistent, perennial, dramatic cycles of rebirth and growth, of Life renewing and resurrecting in shoots and buds.

One of the most accessible symbols of higher, divine, spiritual realms is the circle or ring. It is present in the image of the eternal, majestic and transcendent expressed by archetypal spinners and weavers such as the Moirae or Parcae, Atropos, Lachesis and Clotho, mistresses of rhythms and cyclic movement, ${ }^{39}$ who measure out human life-spans. Their spindles, impelled by a bow or the pedal of a wheel and endlessly turning, are a metaphor for life forever ongoing, a never-ending journey in a cosmos in which we now know there are, ultimately, no straight lines and where even empty space is curved.$^{40}$ Whether associated with spinning or the wheels of astral chariots on a sidereal journey, the wheel can signify endless and rhythmic cycles of egress and return. The symbol of the zodiacal wheel is found in almost every culture, and the sun's orbit through the zodiac marks for humans the rim of the cosmic wheel. Whether still or in motion, with or without spokes, whether represented by a swastika, triskele, chakra or spiral, the wheel 'is revealed as a fundamental archetype of organised cyclical victory, law triumphing over the apparent unruly confusion of an ever-changing world'. 41

Latin words for beginning, like ordiri, exordium and primordia, referred initially to setting the threads of the warp on the loom. Thread, itself a statement of continuity, is derived from the plant world that Dionysus galvanises and cel-

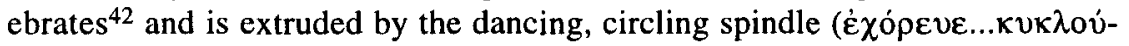
$\mu \varepsilon v o \zeta, 6.149$ ). Thread is woven on the cosmic loom by entities such as Athene into a cloth or fabric of plant tissue that is the antithesis of discontinuity. Her tapestry is a higher correspondence to both the fabric woven by mortals at the loom and the patterns in time and space woven by terrestrial dancers, singers 


\section{LIFE AND DEATH IN NONNUS' DIONYSIACA}

and musicians. The garlanded Seasons weave patterns as they spiral in the dance and the Pierides weave songs as they dance. ${ }^{43}$ Deities, including the Muses, descend to weave tunes with song and musical instruments at the wedding of Cadmus and Harmonia (5.88-112). Dance, when it combines sound, movement and direction, readily suggests weaving the fabric of creation. Dionysus' followers are well-circling, ${ }^{44}$ many-circling ( $\pi \circ \lambda \cup$ vv $v \kappa \circ \varsigma$ ) danceweavers. ${ }^{45}$ By their circling and spiralling movements they create space and imitate thereby both the divine dancers and the cosmic weavers. Microcosmically they are like the Hindu Lord of the Dance, Shiva, sending forth, like a pulsar, rhythmic waves of vivifying sound with their drums, tambourines and clappers. They participate mimetically in the celestial chorus by weaving patterns in time with song and music. ${ }^{46}$ Woven fabric, whether woven by sounds, dances or threads, becomes a symbol for the Dionysiaca, where so many things fuse with or correspond to other things and the interrelatedness and interchangeability of everything is stressed. When things are already predisposed to change into their opposites, opportunities for harmonisation are abundant and likely to succeed. In flowers, prominent subjects in the iconography of the sacred, one sees this fusion of contrarieties, the temporal and time-bound, and the atemporal and time-transcendent. Blossoms bud, bloom and wither, but also physically demonstrate life's recurrent cycles by their (commonly) circular form.

An element that links grief and beauty is rhythm. Mourners typically rock back and forth or engage in some form of rhythmic behaviour, such as rhythmic lamentation, to alleviate distress. To be possessed and charged by beauty is to banish the void. Muscular, kinaesthetic activity recharges the sense of touch and sensation that is threatened with impoverishment at the loss of intimacy with what is loved and cherished, be it a relative, friend, leader, homeland. It reassures that all identity has not been lost when loss and a sense of abandonment pose just this question. By mobilising bodies in a pleasurable, holistic and harmonious way, by interacting with the positive stuff of space, dance is particularly therapeutic. Nonnus does not explicitly mention rocking in his descriptions of grief, and rhythmic lamentation can only be presumed. However, the music, song and woven dance (19.119) that follows the death of Staphylus, in honour of a man who loved the dance (19.150), clearly contains rhythmic activity. ${ }^{47}$ Rhythm can be present in any form of art. Its physiological presence in song, dance, chant and instrumental music is particularly obvious, and represents a sublimation of the notion that rhythm (such as in sexual intercourse) is fundamental to fertility, creation, procreation and the affirmation of life. The erotic associations of music are particularly obvious in strong, percussive rhythms. ${ }^{48}$ Besides emphasising the link between music and sexuality, these rhythms (as mentioned earlier) can charge the brain with an intensely pleasurable sense of fullness. ${ }^{49}$ Rhythmic music keeps individuals in step with the dance-leader and as it moves consciousness towards trance and the sense of being possessed, it prepares the individual to be filled, breathed into, inspired by some larger force or presence. ${ }^{50}$ As Pythagoras, for one, maintained, correct sounds 


\section{R. NEWBOLD}

call forth cosmos from chaos. They could also bring the order of heaven down to earth. This merging and fusing is a consequence of one of music's most signal properties, its capacity to appropriately arrange or harmonise opposites, contrasts and differences. ${ }^{51}$

Further to the matter of rhythm: as Plato puts it, rhythm was given to us by the Muses to provide the measure and grace that most of humanity lacks, so that we become more like gods. ${ }^{52}$ 'Measure' which, like 'metre', is from the Latin metiri ('to measure, to walk with measured tread'), and is etymologically

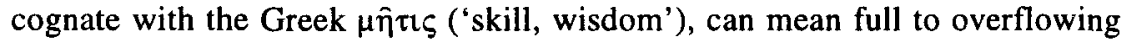
when it occurs in the phrase 'in good/full measure'. Beat, rhythm, metre are essential to early technological innovators, musicians and poet-creators ${ }^{53}$ and to dancers as they amplify the drumbeat and beat out the measures and patterns of wisdom. Thus, driven by a longing and sense of lack, they fill the void and bridge the chasm between humanity and the earthly planes, and the joyful heavenly planes where the star-gods shine, gyrate and utter (cf. 13.413-15, 38.38083). They align with forces of nature, gain some control over time, and feed the innate hunger for eternal beauty. ${ }^{54}$

A musical or rhythmic universe of fluctuating fields is characteristic of the astrobiological outlook. ${ }^{55} \dot{\rho} v \theta \mu o ́ \zeta$ is not that common a word in Nonnus (occurring 17 times) but has an interesting range of applications: the cycle of the years, the movement of the cosmos on its axis, the drumming and dancing of the Corybants and the Curetes, string and wind music, song, weaving. Harmony rests upon the reconciliation of antitheses such as above and below, life and death, mortal and immortal, male and female. Hence the key role in the poem of Physis, Rhea, Astraea and Harmonia (both Harmonia the wife of Cadmus, daughter of Ares and Aphrodite, and Harmonia the great deified virtue and cosmic nurse), as well as those two forces that make for harmony through love and marriage, Eros and Aphrodite. Without harmony there is no life. In a sense harmony is life. When a half-dead serpent is revived by a herb, it is $\dot{\alpha} \rho \mu o v i \eta$ that returns to its body (25.551). Conflict and its right resolution are necessary parts of the process whereby harmony is achieved. Nonnus' cosmos is fertile, sexualised, pullulating with life, but when harmony breaks down, as it does in Books 1, 2, 6, 24 and 38, or when harmony and order are threatened in Books $23,32,36$ and 48 , barrenness and sterility result. Life and harmony retreat on several fronts: no weddings, ${ }^{56}$ no births, no ploughed fields, no music, no dances by the Graces when, for example, Aphrodite usurps Athene's role as cosmic weaver and fails miserably. ${ }^{57}$ The celestial and terrestrial chaos caused by Typhon's insurgency meant that Eros, 'primeval founder of fecund marriage', is no longer able to fire his arrows to bring potential begetters of life together and so the universe is adrift, its joints asunder, and it no longer holds a system or harmony together. Cadmus, instrumental in the eventual restoration of Zeus' celestial order through the music which he plays for Typhon and which temporarily masters the monster, is regarded by Zeus as 'saviour of the world's harmony' and is fittingly promised the hand of Harmonia. ${ }^{58}$ When the chaos in 


\section{LIFE AND DEATH IN NONNUS' DIONYSIACA}

heaven and on earth wrought by Phaethon's disordered drive of Helios' chariot was terminated by Zeus who 'fixed again the joints which held all together with their primeval union', the earth and its vegetation laughed again (38.412-16), just as when Eros did his job and marriage and conjugal rites ensured fertility.

To review: loss can spur people seek to fill the barren void by creating (or procreating) something new, something that helps to fill an empty space and replace the loss. Or they engage in some activity which reconnects with the group and the environment, and thus alleviate a sense of abandonment and isolation. Prolonged participation in group chanting, drumming and dancing leads to synchronisations of heart-rates and brainwaves, reinforcing a sense of oneness. Rhythm is contagious. The beauty of nature, its greenery and life-force, can be a solace. By reproducing the movements of heavenly bodies, rhythmic and/or circular activity are thought to promote natural fertility and good order. The repetitions and cycles of nature are held to originate from celestial archetypes. ${ }^{59}$ The Dionysiaca is replete with means to fill whatever aching emptiness threatens mortals' sense of self: company, vigorous movement, nature, multiple forms of fertilisation, new life perpetually emerging from death, sound and rhythm. For immortals, consolation may lie in the emergence of new life forms, such as the iris or vine (Hyacinthus, 3.152-63; Ampelus, 12.173-87), or the resumption of activities dear to them, such as the harvest home (Demeter, 1.91f., 2.650-59).

Dance, $\chi$ opei $\alpha$, is, as we have seen, characteristic of visions of the afterlife. The harmonious choral order of paradise intensifies the joy and the experience of heaven's radiant beauty for its denizens. Like music, it has erotic, healing, cheering, consciousness-altering and intoxicating properties. Barriers and prisons dissolve. Besides being a source of delight, dance can symbolise social order and harmony. Dance is omnipresent in the Dionysiaca, the epic journey of Dionysus from womb, where he dances (8.27-29), to Olympus, reached after much terrestrial journeying and a number of setbacks. All manner of people and creatures (gods, Justice, pans, nymphs, trees, animals, the Seasons, Time's daughters the Hours), as well as rivers and hills, dance on all sorts of occasions in all kinds of places (in battle, Semele's bedroom, Staphylus' funeral, during an earthquake), endlessly wheeling like Corybants, circling, cycling, interlacing and spiralling, and to the extent that they imitate the creative, harmonising Muses and the chorus of the celestial bodies, they weave within the great round orbit and wheel of Time beautiful, intricate, spiralling geometric patterns and dances. ${ }^{60}$ The wording of the previous sentence is an attempt to convey the redundancy of Nonnus' style, whereby, for example, words denoting roundness or circular movement cluster together and somewhat superfluously reinforce each other, so we get phrases like 'the roundness of the circling orbit' or 'the circle of the round rim'.61 Evident from Hesiod onwards is the connection in GrecoRoman culture between choral dancing and cosmic order, the belief in dance as a means of harmonising and entraining the earthly planes with the celestial and transcendent realms and thus participating in a larger cyclical order which mani- 


\section{R. NEWBOLD}

fests in accordance with the principle of redundancy. ${ }^{62} \mathrm{~A}$ bridge is woven between heaven and earth, a chasm is bridged, fertility is enhanced, a sacred marriage (hierogamy) is consummated, Nature and one's own nature are both enhanced. To conform with the spiral in particular is to harmonise with the emblem of life in motion, to acknowledge intuitively the helices of the DNA molecule and the path by which chaos evolves to order and harmony.

Circularity, then, is a major motif in Nonnus, whether it is the roundness of objects, of surfaces and of parts of the body, the paths taken by dancers or heavenly bodies, or various spirals, belts and girdles. Some figures are given (see n.64 below) to lend support to this assertion but, before that, a further word on the place of the heavens in the poem. Descriptions of heavenly events, scenes in heaven, heaven imagined about, sending down water or fire from heaven (but not epiphanies of deities on earth) occupy a substantial part of the narrative, about one seventh, 3091 lines out of 21287 (14.5\%). In many different ways, and leaving astrology aside for the moment, what happens above is shown to impact upon or control terrestrial existence, obviously so in the case of heavensent weather, moon-influenced tides, ${ }^{62}$ heaven-ordered diurnal, seasonal and annual cycles, and deities who intervene to influence, create or destroy life on earth, but also the Fates who determine and terminate individual lives, and the tablets of Time which set forth the course of humanity over a Great or Cosmic Year, almost 26,000 solar years. In Nonnus we have met the idea, common in antiquity, that in the heavens there are archetypal forms (mainly spherical and circular), sounds, activities (such as weaving) and patterns of movement (spiral and orbital) that humanity is well advised to reproduce, as far as that is possible, on earth. In this way, too, terrestrial life is shaped from above as it seeks to harmonise with the archetypes and thereby reduce the separating gap. The harmony (order, concord, union, dispensation) of the cosmos, personified as Harmonia, already dwells in heaven in a round structure that reflects the cosmos, the higher counterpart to that Harmonia who was the daughter of the deities of love and war, Aphrodite and Ares, and wife of Cadmus. ${ }^{64}$

To engage in an activity such as sacred dance, the foundation of a city, or the construction and orientation of a temple or circle of stones was to participate in a reality that is regarded as transcending time and partaking of the perennial. It recollects a primordial time, it reflects a celestial archetype, it helps to ensure a pattern of meteorological and celestial order, which in turn ensures order and longevity in the state or community. ${ }^{65} \mathrm{~A}$ good example of just this replication of primordial reality is the scene in Book 22 where humans, nymphs, fierce beasts, trees, streams and the earth join to create a symphony and ballet of music and dance that recalls the harmony, effortless fertility, peace and joy of the Golden Age (22.1-54). A different approach to capturing primordial timelessness is Cadmus making seven-gated Thebes a sacred city, a symbolic and microcosmic reflection of features of the heavens, as he measures and lays out the foundations, dedicating each gate to the sun, moon and five planets, and 'decking out an earthly image like to Olympos' ${ }^{66}$ Thebes' interior space is then 


\section{LIFE AND DEATH IN NONNUS' DIONYSIACA}

filled and woven with garlands, music, song and a variety of dances. ${ }^{67}$ Human marriage, or copulation in the fields, too, can re-enact a primordial hierogamy, such as that between heaven and earth, and be thought to promote the fertility of the soil. ${ }^{68}$

There is linear progress and historical necessity in the Dionysiaca, at least within a great, cosmic year, as well as endless cycles and unchanging, eternal returns which give time a finite as well as infinite quality. ${ }^{69}$ Astronomy tracks the movements, cycles and helical risings of these bodies, astrology and astrological divination seek to understand and explain just how their influence operates on terrestrial life and what the stars foretell for humans. From seeking to understand the laws of the universe by observing the periodic celestial movements, it is an easy step to believe that in heaven are tablets that 'lay down the law' (law in both the strictly legal, and loosely legal sense of commanding) for humanity and contain its future. ${ }^{70}$ If celestial beings control the passing of time by marking and measuring it, this activity on earth should not only be an act of harmonisation with higher powers, but should also assert a degree of control over time as one enters the sacred reality of primordial time. Ideas about necessity are easily fused with those about harmony and stability. ${ }^{71}$ The mathematical calculations which related celestial movements with terrestrial phenomena are a constant and measurable connection (and very necessary for sowing at the right time and maximising crop yields), and challenged the caprice of a simple, generalised, pre-astrobiological vitalism or animism. One sees again why beating the measures of song or dance is considered so important for understanding and harmonising with the life force that soars and swirls through Nonnus'

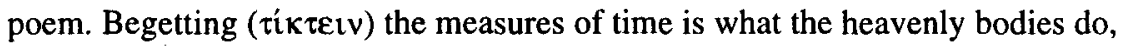
rhythmically creating. ${ }^{72}$ Nonnus' bio-astral theology is irreducibly cyclic but therein historical, temporal necessity and linearity also rule. Humanity benefits not just from better cities (6.383-86) and the inventions mentioned earlier (n.69 above) but from the earth becoming more fruitful as a result of Dionysus' new dances and orgiastic activity. The appropriate figure here is the spiral, which combines linearity with curve, and incorporates even more forcefully the idea of motion. ${ }^{73}$

Stars and planets have an anthropomorphic and biological nature, particularly obvious in the case of recent catasterisms (Semele, Ariadne, Icarius, Erigone, Phaethon), and terrestrial living organisms are considered to be subject to the influence of these heavenly and anthropomorphic bodies. Conversely, heaven is subject to emissions from earth, whether the chants of Bacchants, the drums of Corybants, the voice of Dionysus, the sounds of battle, even the lights of revellers. ${ }^{74}$ Analogy and a perception of often heavily symbolic correspondences between upper and lower realms elaborate and sustain the fabric of vertical relationships, so that attention oscillates between the heavenly and sidereal macrocosm, and the human or terrestrial microcosm. A good example involves Ariadne, destined to become the constellation Corona, 'a starry crown... [and] the shining bedfellow of crownloving [ $\phi \imath \lambda$ ó $\sigma \tau \varepsilon \phi \alpha v o \varsigma$, applied on three other occa- 


\section{R. NEWBOLD}

sions to the god] Dionysos'. For her, on earth, Eros 'made a round flowergarland with red roses and plaited a wreath coloured like the stars, as prophet and herald of the heavenly Crown'. Further isotopy of circularity, dance, wedded love, fecundity, long cycles of time and immortality is evident when one takes 'And round the Naxian bride danced a swarm of the Loves which attend on marriage. [The god] entering the chamber of wedded love sowed the seed of many children. Then rolling the long cycle of hoary time...' (47.451-72), with Dionysus' last terrestrial feat, elevating to heaven 'the rounded [ $\pi \varepsilon \rho i \kappa v \kappa \lambda \circ \varsigma$ ] crown of Ariadne passed away, a witness of his love, and everlasting proclaimer of garlanded [ $\phi \imath \lambda o ́ \sigma \tau \varepsilon \phi \alpha v o \zeta]$ wedding' (48.971f.).

To review: on the one hand, we have the zodiacal perspective and gigantic, almost limitless, temporal cycles presided over by deities, and the tablets of Aeon, one of which was as 'old as the infinite past, containing all things in one' (12.43f.), and Allmother Harmonia, consulted by Zeus, Demeter and the Seasons. On the other hand, we have the loss and mortality of humans and animals. And we have the endless circling, weaving and spiralling that in astrobiological thought mediate and bridge these contrarieties, creating a voidless continuum. That is why Nonnus' epic begins with two books of dramatic cosmic conflict, war in the heavens between Zeus and Typhon, which is, crucially, determined by the actions of the mortal Cadmus. That is why Nonnus must include the marriage of Dionysus' maternal grandparents, Cadmus and Aphrodite's daughter Harmonia, who, despite the music and dancing and Olympian presence at their wedding, are unable to escape their destiny to metamorphose into serpents. This is the drama that they live out and the fate they eventually succumb to. Nor can the immortal Persephone and the Indian leader Deriades escape their fates. That is why the work contains much astrology, however faulty and confused at times, because the positions and movements of heavenly bodies are considered to be major determinants of individual destinies. They imprint the higher upon the lower. ${ }^{75}$

To conclude: winning fame that endures in human memory, being honoured and respected when dead, graven epitaphs, metamorphosis into an ongoing form, such as a river or plant, offer partial victories over death. Otherwise, apart from catasterism in a celestial vault that can accommodate new arrivals, mortals can only assume that the sounds they utter, the patterns they create and the rituals they perform really do harmonise with the macrocosm and align with the higher levels, and thus hope that they will thereby remain a sentient part of some greater living whole. Imitating cosmic creators means participating in activity that sustains life everywhere. It is a generalised, diffuse immortality that is on offer, not a guaranteed abode in a discrete heaven or paradise. Those who, like Silenus, dance into death, who deathleap into a new life, or who were initiated into the mysteries, would appear to have fair or good prospects of being reborn on the wave of an ever-flowing cosmos. ${ }^{76}$ The earth is both fecund and funerary. It is where seeds are buried and from where they are reborn into a new life, thus providing an analogue of the human condition. Although war on a 


\section{LIFE AND DEATH IN NONNUS' DIONYSIACA}

higher plane between the Olympians is one of many nods in the direction of Homer, Nonnus' astrobiology requires that conflict between Bacchants and Indians on the ground be reprised by conflict in the heavens, just as eroticism (often transmitted by Eros' arrows) and harmonising activities in heaven, such as dance and weaving, are reprised on earth by efflorescent vegetation, orgiastic and choreographic revelry, circular movement and the throbbing drums that arouse sexual desire.

The endless disappearance and return of the heavenly bodies, the sense of eternity that they convey, the rhythm of the seasons that are determined by celestial movement, and the various terrestrial activities that strive to harmonise the lower with the higher and so transcend time, all these encourage belief in immortality, for some at least. Activities such as song, music making, dance and weaving were ways of feeling at one with a continuous fabric of creation that fills the emptiness and pain of loss, bereavement and isolation, and fortifies against the fear of complete personal extinction and oblivion. Refusal or inability to tap into this resource, or to ride the dynamic, eddying, joyful stream of Life, exposes the afflicted to despair and suicide.

In the Dionysiaca, only Dionysus reaches Olympus and only a favoured few live on as stars, plants, rivers or landmarks, in some cases thereby cushioning immortals from a sense of loss. Hades is the presumed destination of the rest but the supercharged power of the drive towards rebirth, possibly in a new shape, suggests that sojourns there will only be temporary, unless something happens in heaven or from above to render barren and infertile the soil that contains the seeds that are like celestial gateways to new life. What Nonnus' poem leaves unclear is the extent to which individual particles of humanity retain their unique identity when swept into life's vortices ${ }^{77}$ but this is not surprising in a poem that celebrates transcendent Life. Dancers, whether they be members of a real astrobiological society or Nonnus' imaginary one, whirled, spun and gyrated, and ate, drank and chanted together. We cannot know whether, as they did this, they thought, or were imagined as thinking, much beyond enhancing the fertility of the land and its inhabitants, and elevating their mood and honouring deity. We cannot know to what extent they pondered, or were meant to ponder, like Dervishes do, upon the cosmic, harmonising significance of their movements, and just what it meant for their own futures. Intoxication or ecstatic trance do not necessarily confer insight into cosmological secrets that are then acted upon. Intimations of immortality and apperception of transcendent beauty and harmony gained through attuning to macrocosmic patterns do not necessarily uplift character or enhance inter-personal skills.

\section{University of Adelaide}




\section{R. NEWBOLD}

\section{NOTES}

1. The Marriage of Cadmus and Harmony (London 1993), 330. The cosmological secrets that Calasso perceives are (i) the conception of matter and form as relatively malleable and essentially unstable and shifting, in a perpetual state of 'churning variegation', free from fetters and rigidities that confine and ossify; and (ii) the principle of redundancy. These, says Calasso, form the vision of divinity at the heart of the poem (331).

2. One should add that nature (trees, rocks, Mt Cithaeron) can also weep and groan in mourning the dead: see 12.117, 121, 123-32 (rivers ceasing to flow); 15.370, 372-422; 46.441-64.

3. I1.224-368, 482f:; 12.101f. Dionysus may not be able to shed tears but, despite what Maron says, he can certainly mourn (19.169f.).

4. W. McNeill's Keeping Together in Time: Dance and Drill in History (Cambridge MA 1995) is a study of how moving muscles and giving voice rhythmically strengthen interpersonal bonds, reintegrate the bereft, elevate mood and, often, arouse libido.

5. On the connection between beauty, sorrow and touch, see J. Chodorow, Dance Therapy and Depth Psychology (London 1991), 88. As, for example, the Homeric Hymn to Demeter so clearly illustrates, the sorrow of loss is akin to losing one's normal abode for a barren wasteland. However, such an experience can ultimately enhance our experience with the earth and the physical, tangible world. P. Ekman and R. Davidson (edd.), The Nature of Emotion: Fundamental Questions (Oxford 1991), 17 and 252-57, rehearse the arguments for and against the universality of affects such as grief. While certain emotions are universal in the pattern of their autonomic nervous activity (e.g. pulse, blood pressure, respiration) and in some distinct signals, their zetiology and expressive behaviour are culturally determined. On the stages and wide aetiology of grief, see E. Bruce and C. Schulz, Nonfinite Loss and Grief (Baltimore 2001), 17-22.

6. 5.370-551. Icarius appears in a dream to tell Erigone what has happened to him but he had already been placed in a tomb (47.148-213).

7. $46.360 \mathrm{f}$. Translation here and henceforth by W. Rouse, Nonnos: Dionysiaca ( 3 vols., Cambridge MA \& London 1940-46).

8. 19.12-26; cf. 47.42, 53-55, 93, on wine as painkiller and trouble-dissolver. Not that everyone, notably the Indians, was willing to receive this gift.

9. 46.356-60. Immortals do pity the sufferings of mortals, as the above actions by Zeus and Dionysus indicate. Among the reasons Time/Aeon pities humanity and threatens to quit his job unless Zeus does something to lighten humanity's lot is War/Enyo's unceasing 'harvest of quickperishing youth' (7.22-66). He challenged Zeus to find a way of bringing more joy to suffering humanity, which Zeus did by bringing forth Dionysus to spread viticulture and new dances that could transform pain into ecstasy. Time rates banishing sorrow (which must include bereavement grief) as superior to the gift of fire. Later, as patron of drama, Dionysus helped to heal the pain of loss and other sorrows through tragedy and comedy. And Apollo pities the sufferings of Ino driven mad by Hera (9.275-89).

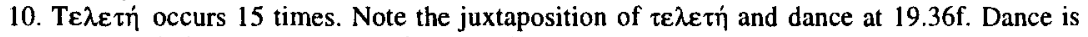
often part of initiation ceremonies. Múotıక and cognate words occur 48 times. Dionysus' nurse, Mystis, initiated him into mysteries which in turn became available to mortals (9.111-31). There is reference to the Samothracian mysteries and dancing, drumming Corybants at 3.41-44, 62-64. Apart from the mysteries of Dionysus, there were the initiations and secret guilds of the Telchines, Cabiri, Curetes, and Dactyls, variously associated with magic, dance, exposure to the secrets of Nature, and metallurgy. All these guilds are mentioned in Nonnus.

11. For many, hope is an antidote to the pain of some kind of loss. Hope only occurs in the noun form, $\dot{\varepsilon} \lambda \boldsymbol{\pi}$ í, in Nonnus 44 times. Twenty-five times it is hope for a victory in or prizes from war or a contest, three times to become a star, twice for security and reaching Olympus, once for wealth, safety at sea, dulling the pain of bereavement, to become white-skinned. In other words, hope in Nonnus is mainly directed at winning prestige and security for the self, advantage and status over others.

12. She is made to complain that Cetus still threatens her in the sky (25.123-43).

13. 38.424-34. The way Phaethon was mourned by his weeping sisters, who became trees that exuded amber, would have been sufficient to immortalise his memory.

14. 21.153f. The catasterism as Bootes of Callisto's son, Arcas, by Zeus is another example of a sympathy elevation, perhaps driven by the wish to make things up to his mother (13.296f.). 


\section{LIFE AND DEATH IN NONNUS’ DIONYSIACA}

15. 42.205f.; cf. 200-04. More positively, Eros later assures Dionysus of greater success with Ariadne and Pallene (43.422-36). Less so, Eros finds something particularly attractive about the grief of abandoned Ariadne (47.311-18).

16. 4.64-66, 209. But Echo re-echoing Philomela's groans at the loss of her tongue and virginity hardly counts $(4.327 f$.).

17. 1.352-55. And although not stated by Nonnus, gives her name to a continent. Nicaea experiences a similar loss and gain. But Aura can in no way be recompensed by prestigious parenthood for the loss of her virginity to rape. Bearing twins to Dionysus, she kills one and tries to kill the other, the cult-significant Iacchus, before committing suicide (48.910-27).

18. 6.58-102. In two other cases of feared loss, Hades' fear that he will lose his kingdom in the cosmic battle proves idle (36.97-105), and Psamathe, fearing the victory of Dionysus over water deities, averts this by successfully praying to Zeus (42.358-74)

19. The distress felt by Aeon at the damage to humanity caused by Aphrodite's clumsy weaving ends when she returns the task to Athene (24.242-326), the grief of Methe and the Bacchants at Dionysus' absence disappears when he returns (19.198f.; 21.184-99), as does the yearning of Priasus for his father and homeland when prolonged floods subside and he can return home (13.521-44).

20. Battles lost by the Indians stay lost $(24.69-178 ; 25.274-79)$, Pan's love for Echo remains unrequited (16.321-40), while Bacchants who lose their freedom to the Indians eventually drown (34.231-48)

21. These characteristics have been noted by a number of scholars, such as $\mathrm{L}$. Chamberlayne, 'A Study of Nonnus', $S P h 13$ (1916), 40-68, at 57: 'Monstrous and heartless cruelty everywhere...lack of sympathy and pity.' Cf. G. Braden, 'Nonnos Typhoon: Dionysiaca Books I and II', Texas Studies in Language and Literature 15 (1974) 851-79, at $865 f$.

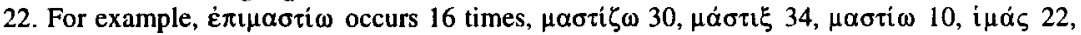
i $\mu \alpha \dot{\alpha} \sigma \lambda \eta$ 44, i $\mu \dot{\alpha} \sigma \sigma \omega 66$, total 222.

23. J. Winkler, In Pursuit of the Nymphs: Comedy and Sex in Nonnos' Tales of Dionysos (Diss. Texas 1974), 68, speaks of a prevalent anaesthesia. On the poem's psychology of isolation, see A. Wifstrand, Von Kallimachus zu Nonnos (Lund 1933), 142.

24. S. Bertman, referring specifically to the honouring, 'repositioning and revival of the loved one in an inner time and space', in her editor's introduction to the anthology, Grief and the Healing Arts: Creativity as Therapy (New York 1999), 15. This work illustrates the many resources, including music, song, all the visual and dramatic arts, ritual and therapeutic touch, which are available to heal individual and communal grief and loss. Music has a special ability to heal, reconnect and 'touch' the mourner.

25. Breasts, for example, shoot forth not just milk and wine but light, lightning, fire, arrows. Wombs shoot forth infants.

26. Some examples of these features: precious stones not so much emitting or radiating light but spitting or shooting it forth $(5.170,175)$, river banks spitting roses $(10.171)$, Tyrian cloth shooting out purple sparks (40.305). Cf. 15.164 and the remarkable passage at $35.164-83$. Semen, blood, serpent's teeth, urine and ichor can mix fruitfully with the earth, ox-hide or water to produce centaurs, Erechtheus, Orion, Gamos, and Aphrodite. Objects ranging from sails to wine vats are not so much filled or full, but pregnant with something. Despite or perhaps because successful instances of 'normal' sexual relations are rare or compromised in some way, almost anything can impregnate almost anything, and fertility and fertilisation and the generation of new forms are so rampant as to be almost out of control. See Winkler (n.23 above), 70-113, on many instances of bizarre and irregular conception, parturition and lactation (animals, virgins and men who suckle human infants), and 130-38 on the often gratuitous male-female gender demarcations, such as male and female rocks (2.495-500), palm trees (3.142f.), lyre sounds (19.79). Another mark of the dynamism of Nonnus' world is the number of $\alpha$ vito-compounds. Spontaneous generation (42 instances), growth and impulse from within are ubiquitous. See J. Lindsay, Leisure and Pleasure in Roman Egypt (London 1965), 377, 388, 455, on the 35 different words for self-spiralling, selfcircling, self-rolling (e.g., wheels), self-growing etc., used altogether 292 times.

27. See R. Shorrock, The Challenge of Epic: Allusive Engagement in the Dionysiaca of Nonnus (Leiden 2001), $115 f$.

28. For example, on the prevalent Nonnian motif of scratching and scoring solid or liquid surfaces, or the insubstantial air, see M. Reimschneider, 'Der Stil des Nonnos', 48f. and 57, in Aus der byzantinische Arbeit der DDR 1 (Berlin 1957). Г $\rho \alpha \dot{\phi} \omega$ and cognates occur 50 times, $\chi \alpha \rho-$

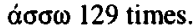




\section{R. NEWBOLD}

29. Cf. M. Lindfield, The Dance of Change (London 1986), 25: 'The molecules of matter dance to and fro, influenced by the forces binding them into substance. These movements seem to follow certain patterns and manifest themselves in rhythmic periodicities.' Certain forms of dance, imitating and thus harmonising with the movements of heavenly bodies, can therefore be seen as both cosmically resonant and terrestrially procreative. See S. Cole, Landscapes, Gender, and Ritual Space (Berkeley 2004), 10 and 14.

30. Such vigorous activity is in keeping with Nonnus' baroque style which revels in superfluity. Scenes and artefacts are painted and decorated in elaborate, sometimes cloying, detail. Vocabulary and phrasing convey a sense of bubbling, explosive, frenzied energy, a maelstrom that is only partly contained. See R. Newbold, 'The Character and Content of Water in Nonnus and Claudian', Ramus 30 (2001), 169-89, esp. 176-78. On Nonnus' style, see G. Braden, The Classics and English Renaissance Poetry (Yale 1978), 70-72, especially the apt phrase, 'a prevalent sensation of explosions under a thickly lacquered surface' (72); M. Whitby, 'From Moschus to Nonnus: the Evolution of the Nonnian Style', in N. Hopkinson (ed.), Studies in the Dionysiaca of Nonnus (Cambridge 1994), 99-155, esp. 123 on its energy, variety and innovation. Horror uacui, which, at least in part, is a response to separation anxiety, prevails.

31. From redundare, 'to flow freely' or 'to overflow'.

32. There is wisdom, therefore, in those cultures which include aesthetic and life-affirming activities, such as floral displays, song, music and dance, at funeral rites, even if the performers are few. Cf. the words of Maron: 'I will dance for Staphylos after death, as if he were living...For you I dance, Staphylos, both living and not breathing, and strike up a funeral revel' (19.178-81).

33. On the isotopy of the void, barrenness and separation from the divine, see J. Barrow, The Book of Nothing (New York 2000), 39 and 65f.

34. Timaeus 41d, 42b. Cf. Aristophanes, Peace 832f., Cicero Republic 6.13 and for this idea in late antiquity, M.-C. Fayant, Nonnos de Panopolis: Les Dionysiaques Chant XLVII (Paris 2003), 26-38. For Nonnus' eclectic embrace of all the dominant concepts of his day, from alchemy to astronomy and ritual dance, see Lindsay (n.26 above), 88 and 369: 'He is the poet of alchemic process' (371). On the elevation of the afterlife from the sublunary and chthonic to the celestial and transcendent in antiquity, see W. Thompson, 'The Evolution of the Afterlife', Journal of Consciousness Studies, 7.8 (2002), 61-72.

35. 31.30-74. Nonnus eschews evocations of the infernal world so dear to Latin poets.

36. Nature: $3.10-16,55-76 ; 11.495-500 ; 40.338-52$ (of the site of Tyre: 'never have I beheld such beauty...image of the earth, picture of the sky'). Artefacts: the wedding-gift necklace of Harmonia (5.144-89); the shield of Dionysus with its 'crown of many shining jewels throughout the seven zones' and 'sparkling company of the stars' (25.384-567); and beautiful buildings, such as the palace of Staphylus (18.67-92).

37. The brilliance and lustre of precious stones may have this reminiscent effect on some, but not, it seems, in Nonnus. See H. Frangoulis, 'Les pierres magiques dans les Dionysiaques de Nonnos de Panopolis', in D.Accorintini and P. Chuvin (eds.), Des Géants a Dionysos: Melanges F. Vian (Paris 2003), 433-45. J. Armstrong, The Secret Power of Beauty (London 2004), 3, quotes Stendahl: 'Beauty is the promise of happiness.' Whether of a person, object or place, it gives an immediate charge. For those with ears to hear, the heavenly bodies emit sounds, a sort of music of the spheres, and noted by Nonnus at $1.222 \mathrm{f}$., 466f.; $2.172-74 ; 13.359-62,413-15 ; 38.250$. For responses to the beauty of terrestrial sounds see 1.393-95, 406f., 409, 416, 513-54 and 2.9-29 (Typhon); 10.220, 230-34, 276 (Dionysus); 17.67-71 (Dionysus); 19.69-117 (Dionysus and Staphylus' mourners); $41.250-53$ (men). Dionysus' own voice was 'mindcharming' ( $\phi p \varepsilon v o$ $\theta \varepsilon \lambda \gamma \eta \dot{\zeta}, 47.427)$. Emily Dickinson may be overly pessimistic when she says, 'Parting is all we know of heaven,' but she points to the image of the separating gap, gulf, chasm, which this paper suggests may be bridged by, amongst other things, the replication of divine creativity, activity, movement, order.

38. On Nonnus' treatment of the aesthetic and erotic charge of floral and bodily beauty, see Winkler (n.23 above), 20-36, with discussion of many references, and the quotation from Bertman at $\mathbf{n} .24$ above.

39. Cf. 24.262: Pasithea, a Grace, 'whirled [the spindle] with wheel-like quick motion', $\tau$ po-

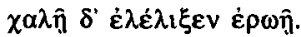

40. This intuition is confirmed by modern physics. Hence the cogency of the idea of inevitable return to a starting point. See F. Capra, The Tao of Physics ${ }^{3}$ (London 1991), 177-207. For peoples such as the Kogi of Colombia, the cosmos is a spindle, whose thread the sun weaves into the fab- 


\section{LIFE AND DEATH IN NONNUS' DIONYSIACA}

ric of existence. The wobbling or spiralling movement of the earth's axis is typically described by images of the churn, mill, wheel, spinning top-and spindle.

41. G. Durand, The Anthropological Structures of the Imaginary (Brisbane 1999), 317. Nonnus likens to the roundness of a wheel cheeses, the breasts of Semele and Pallene, the Cyclops' eye, the moon, the moming star, Ocean, the whirling of the Corybants, a shield boss, the celestial vault, and, most significantly if traditionally, the justice of Nemesis (three times). See Lindsay (n.26 above), $377,387 \mathrm{f}$. and 455 , on the proliferation of circle and spiral imagery and its closeness to alchemical thought: 'Nonnos' Dionysiac spirals also are tensional movements linking all things and creating structures as well as the collisions of transformations' (455).

42. For example, his approach to Thebes is associated with luxuriant vegetation (44.127-29). Cf. 10.141-74.

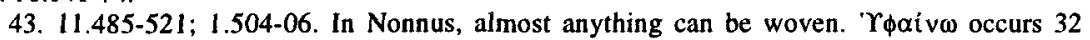
times, $\pi \lambda \varepsilon \dot{\varepsilon} \omega$ and cognates 123 times.

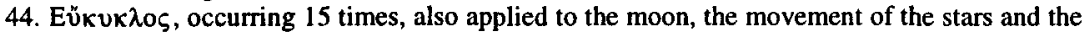
heavenly vault.

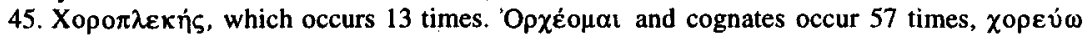
and cognates 230 times. For a discussion of the poem's weaving, spiral, circle and dance motifs, see R. Newbold, 'Chaos Theory in Nonnus' Dionysiaca', Scholia 8 (1999), 37-51.

46. 40.222-33. Cf. Durand (n.41 above), 310-12, esp. 311: 'There is an obvious isotopy between plant and man-made "tissue", both of which belong in the schema of continuity, and 312 : 'Thus the technology of textiles, because of the tools it uses, the spinning-wheel and spindle, and because of its products, threads and materials, induces unitary thoughts and reveries of continuity, and of the essential fusion of cosmic contrarieties.'

47. 19.61-284: 'beating of the dance' (144), 'weaving a thythm' (202), 'rhythmic feet' (220). For the way this activity creates and informs space, see further, R. Newbold, 'Space and Scenery in Quintus of Smyrna, Claudian and Nonnus', Ramus 10 (1981), 53-68, esp. 63-66.

48. See Durand (n.41 above), 324: 'Sexual implications structure music as a whole and underlie musical dialogue,' i.e., dialogue between male and female voices, different pitches and timbres, different tones of orchestral instruments. Music is inherently meta-erotic and space- or gapfilling. Cf. B. Holsinger, Music, Body and Dance in Medieval Culture (London 1990), 10 and 3353 , on music, sexuality and human bodies needing to resonate in harmony with the divine; and the first line of Shakespeare's Twelfth Night: 'If music be the food of love, play on,' where the notion of filling a void or empty stomach is explicit.

49. Any group rhythmic behaviour can synchronise brain-wave activity but the loud percussion of drums is particularly effective at effecting such entrainment. See E. D'Aquili, The Spectrum of Ritual (New York 1979), 123 and 245. The sound of the drum very obviously fills space, and deep notes, because their origin is harder to pinpoint, are particularly effective in embracing a group of people. The drum of Shiva, the cosmic dancer and god of creation and destruction to whom Dionysus has been likened, symbolises his creative role. There is by now a substantial body of research on the effects of music on plant germination and growth, e.g., P. Tompkins and C. Bird, The Secret Life of Plants (London 1974), 135-43. The widespread belief in the value of fertility dances may have some basis if it is the beat of feet on the earth that affects plants. The tonoscope is a device whereby sounds are reproduced visually. The beautiful and intricate patterns produced on the screen by some sounds are strongly suggestive of organic growth and justify the description of sonic influences on life as creating a 'wondrously resonating tapestry' (145). For music and dance stimulating growth, see Dionysiaca 47.4-33.

50. Cf. N. Janowitz, Icons of Power: Ritual Practices in Late Antiquity (University Park PA 2002), xi, 61, 65, 84 and 123-26, on the prevalent late antique belief that alignment with and ascension towards heaven and its denizens, leading to astral immortality, was possible if identification with heaven was achieved through uttering the correct sounds and sacred names, or performing the correct rituals and alchemical procedures.

51. Any blending of or dialogue amongst voices, instruments, pitches, volumes, timbres, rhythms is a form of harmonisation, an alchemic coincidentia or coniunctio oppositorum, with sexual overtones. See T. Burckhardt, Alchemy: Science of the Cosmos, Science of the Soul, tr. W. Stoddart (Baltimore 1971), 115, for the view that what artists seek is to capture the rhythms of the inner world and express them in the outer.

52. Timaeus 47e. And as Philo, On the Creation 69-71, puts it, we become like the divine chorus of stars and planets, moving with the wisdom and beauty of perfect music, becoming eternal and in step with cosmic rhythms, and thus overcoming time. Correct rhythm in this belief system 


\section{R. NEWBOLD}

creates a harmonic resonance between heaven and earth. It makes possible the transfer of heavenly beauty and harmony to the earth, an objective of the Dervishes who by their whirling imitate the spinning of the planets and their movement around the sun.

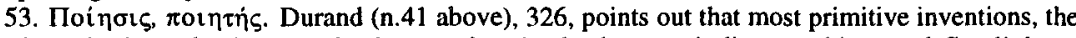
shuttle, spinning wheel, cart wheel, potter's wheel, churn, grinding-machine, and fire lighter, whereby a stick is rapidly rotated in a wooden hole, embody cyclical rhythm and some of them clearly suggest sexual activity.

54. See J. Miller's aptly titled Measures of Wisdom: The Cosmic Dance in Classical and Christian Antiquity (Toronto 1986), esp. 482, quoting from Pseudo-Dionysius the Areopagite, The Divine Names, 4.8-10: 'The divine intellects are said to move in a circle because they are united to the beginningless and endless illuminations of the Beautiful and Good...and in a spiral when they guide needy inferiors while staying in the same state, ceaselessly dancing around the Beautiful and Good, the cause of their self-identity. The human soul also has a circular motion and moves in a spiral manner when it is enlightened with as much divine knowledge as it can receive.' In other words, the pursuit of beauty is part of a project to recall or realise one's essential divine nature, and dance, or at least the right kind of dance, is a pathway open to most.

55. See G. Bertholet, La pensée de l'Asia et l'astrolobiologie (Paris 1949), 7-10, 24, 47, 54 and 65. For Bertholet, the stage of pre-agricultural savagery and nomadism, the Stone Age, characterised by vitalism and animism, precedes the stage of astrobiology, which in turn precedes (but also overlaps with) pre-scientific or scientific culture. Cf. Lindfield (n.29 above), 62: 'Rhythm and motion are the essence of life, and...rhythm is simply motion expressed in balance with harmony.' The gap between astrobiological and scientific thought (sceptical of astrology, for example) is not always wide. The vision, evident in Nonnus, of a dancing, woven, patterned, geometric, harmonic, continually transforming plenum is very close to the perspective of modern forcefield theory and wave mechanics. See R. Lawlor, Sacred Geometry (London 1982), 4. Furthermore, the new science of heliobiology or cosmo-rhythmology, which has come a long way since the $1960 \mathrm{~s}$, includes the study of how the angular position of the moon and planets affects the earth's electro-magnetic biosphere.

56. No 'harmony of wedlock' (3.375). Cf. 26.231-33 for an image that combines wedlock with the fruitfulness of the land.

57. 24.242-73. See V. Stegemann, Astrologie und Universalgeschichte: Interpretationen zu den Dionysiaka des Nonnos von Panopolis (Leipzig 1930), 24-26, on cosmic harmony as the condition of terrestrial fertility, and Winkler (n.23 above), 113-28, which includes the felicitous observation at 118f.: "Nonnus directs our attention to the precepts of his own art. For not only does he relate several tales of chaos surrounded by restored order, but even some of his principles of composition might be described as the unexpected emergence of hidden harmonies out of a conflicting welter of unrelated materials.' Cf. F. Vian, Nonnos de Panopolis: Les Dionysiaques Chants I-II (Paris 1976), 103, on Nonnus' strange orchestration of material in the Typhoneia whereby harmony emerges from dissonances. Winkler op. cit. describes Nonnus' language as frequently 'agri-sexual' (124: gardens, for example, are where plants, fruits and bees have orgies [3.140-52]-flowers, of course, have their sexual organs oriented up and out), language very appropriate for his world of human, animal and vegetable fecundity which depends to a considerable extent on harmonious celestial movements, occasionally threatened or disrupted by cosmic chaos, and terrestrial movements that seek to harmonise with them.

58. 1.395-407. Cf. 2.221-24, where the idea is repeated and elaborated: without Aphrodite to join couples in marriage and without the 'generative arrows' of Eros, 'the universe is without seed. The bonds indissoluble of harmony are dissolved'; $\mathrm{cf}$, also $32.54 \mathrm{f}$.

59. M. Eliade, The Myth of the Eternal Return, tr. W. Trask (New York 1954), 22-26, 34, 90.

60. Cf. 9.116-31, Nonnus' description of the first Bacchant, Mystis, where dance, sound, circles, spirals and weaving are all present.

61. For example, 2.248f., where the circularity of the Ocean is conveyed 6 times in a line and a half: 'Oceanos surrounds the circle of the world...girdling the whole earth coronet-wise with encircling band', and 32.215 , 'the infinite circles of ever-returning years'.

62. Like all those spermatozoa, seeds and eggs that humans, plants and animals produce, and of which only some germinate.

63. And note $38.248 \mathrm{f}$,, 'the moon...the sparkling nourisher of sheafproducing growth', and 44.220-22, where the moon helps to ripen crops. At $46.99-102$, the moon afflicts Pentheus with lunacy. 


\section{LIFE AND DEATH IN NONNUS' DIONYSIACA}

64. The word designating the mortal Harmonia occurs 42 times. The word $\dot{\alpha} p \mu o v i \eta$ otherwise occurs 25 times. The incidence of words for rim, orbit, circle, circular, circling are as follows:

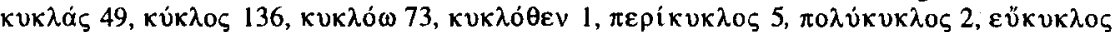

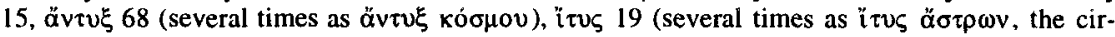
cuit of the stars, or as $i \tau v \zeta \mu \alpha \zeta o i ̄ o$, the circle of a breast). Other words for turning, circling, rolling, wheeling, applicable to dancers, Time, and the path of the Great Bear, include $\tau \rho \circ \chi 0 \varepsilon 1-$

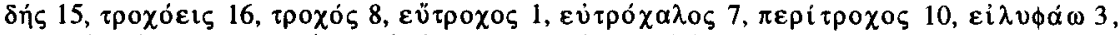

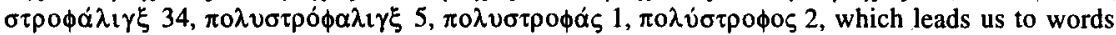

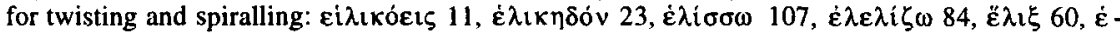

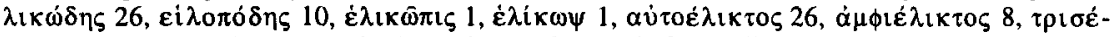

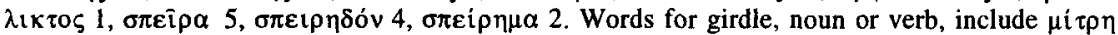

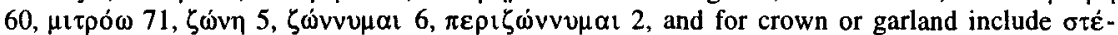

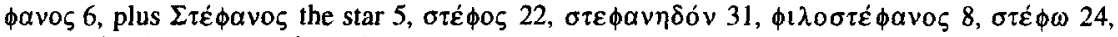

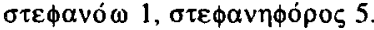

65. See Bertholet (n.55 above), 54-69 and 339-50. Hence temples and stone circles could also serve as observatories. Templa, divisions of terrestrial space, and structures that are usually beautifully ordered and harmonised (but also spaces inscribed by the augur in the sky: cf Greek $\tau \varepsilon \mu \varepsilon v o \varsigma)$, has the same etymology as tempora, divisions of time, and through divination the Etruscans in particular sought through this sacred meeting point of the celestial and terrestrial to ascertain what the heavens portended for humans in the days ahead. Cf. E. Krupp: Echoes of the Ancient Skies: The Astronomy of Lost Civilizations (New York 1983), 217: 'Sacred space is a realm where what we sense to be the basic organisation and meaning of the universe is experienced and celebrated....Astronomical alignments funnel celestial order into prehistoric monuments and turn them into sacred space.'

66. 5.51-87, and the specific parallel between Thebes and seven-zoned heaven at $8.52 \mathrm{f}$. Or Hephaestus representing the many-circled cosmos on Dionysus' shield at 25.384-412. Stegemann (n.57 above), 230-36, sees Thebes as the appropriate source for Dionysian redemptive religion and Dionysus' eventual apotheosis (5.88-113, 280-86).

67. See too Eliade (n.59 above), 4-6, on how rivers, flocks, mountains, fields too can have their celestial archetype, often as a star or constellation.

68. Even more so when a deity is involved. Dionysus' outdoor copulation with Nicaea, described as a wedding, $\gamma \alpha \dot{\alpha} \mu \circ \zeta$, galvanises the natural environment into joyous activity (16.281-91), and foreshadows the celestial, vegetation-stimulating intercourse of Zeus and Hera (32.83-92). Similar intercourse with Aura makes the hill skip and dance, driving itself in a circle, yet another reminder of the many links between sexual activity and choreography (48.639f.). Cf. the energising of plant life produced by Zeus' impregnation of Semele (7.344-47), and what seems to be a surge of plant growth at the wedding of Dionysus and Ariadne (47.456-59).

69. Ordained and laid out in the tablets of Harmonia's universal history by Nonnus, and tabulated by Stegemann (n.57 above), 197-99. Cf. the ouroboros, archetypal symbol of the eternal return, at 33.275-77. Vegetative boons have been conferred upon humanity by Apollo, Aphrodite, Athene and Demeter (12.110-13). Cf. 7.67-105, and culture heroes like Cadmus, Danaus and Aristaeus who introduced to the Greek world writing, astronomy, water-divining, honey-gathering, olive-oil pressing $(4.252-84 ; 5.229-79)$. Nonnus also records the invention of the musical instruments, rock cutting and purple-dyed cloth $(3.75 f$.; $5.56 ; 40.303-10 ; 41.372-76)$.

70. Hence the tablets of Time and Harmonia at 12.29-116 and 41.275-398, the use of numbers to calculate and expound heavenly laws of motion, and the Book of Numbers in the Jewish Pentateuch, depicting Jehovah as God of Order. Doing things by numbers means doing things in an orderly and, generally, harmonious way.

71. The tablets of Harmonia reinforce a sense of future destination with its token of order and stability culminating in the reign of Augustus, and of Roman law in Beirut.

72. $36.396 ; 38.236,251$. Aeon, 'the shepherd of life ever-flowing' holds 'the key of generation' (7.22-28).

73. Miller (n.54 above), 44, suggests that by late antiquity the spiral had overtaken the circle as the 'dominant symbolic configuration in the dance of time'. Because our sun moves around the edge of the Milky Way at $812,000 \mathrm{kph}$ and our galaxy moves around a supercluster of galaxies at $2,250,000 \mathrm{kph}$, sun, planets and stars spiral rather than circle through space. See L. Blair, Rhythms of Vision (New York 1975), 70f.

74. 14.30-32; 40.249f.; 45.332-34; 28.329f.; 24.347 . 


\section{R. NEWBOLD}

75. On the celestial vault as not just a stage where terrestrial myths, such as those involving Orion and Andromeda, are re-enacted but as an actor and protagonist in the Dionysiaca, see $S$. Feraboli, 'Astrologia in Nonno', CL 4 (1985), 43-55. Some of Nonnus' astronomical errors, such as the position of constellations in relation to others, are traceable to errors in his sources, such as Aratus.

76. Silenus dances himself into an ever-dancing, ever-flowing river, a remarkable passage that underlines the capacity of forms to undergo multiple change while retaining part of their original identity. He keeps dancing and maintains an organic connection with Dionysus, wine and the flow of creation (19.285-348).

77. To that extent it is permissible to say that neither Nonnus nor Dionysus has any interest in the afterlife and soteriology. See B. Simon, Nonnos de Panopolis: Les Dionysiaques Chants $X X X V I I-X L$ (Paris 2003), 45 n.1. 